\title{
DEVELOPMENT AND CHARACTERIZATION OF ECO-FRIENDLY SISAL FIBER-NATURAL RUBBER LATEX COMPOSITES
}

\author{
GOPAKUMAR. R \& R. RAJESH
}

Department of Mechanical Engineering, Noorul Isalm University, Thuckalay, Tamil Nadu, India

The toxic, hazardous and non-bio-degradable behavior of synthetic fibers and the rapid depletion of petroleum products from which most synthetic polymers are developed have led the Industries to look for low cost, available and renewable materials like natural fibers for product design and development. The present work aims at the development and Mechanical Properties characterization of an elastomeric composite using natural materials like natural rubber latex and $40 \% v / v$ continuous and unidirectional natural sisal leaf fibers, in both longitudinal $\left(0^{\circ}\right)$ and transverse fiber orientations $\left(90^{\circ}\right)$. Tensile and Tear strengths for Longitudinal $\left(0^{\circ}\right)$ fiber orientations are found to increase by $1428.5 \%$ and $927.1 \%$ respectively over pure latex sample. For the $90^{\circ}$ fiber oriented rubber, latex samples also showed improvements in tensile and tear strengths.
\end{abstract}

KEYWORDS: Rubber Latex; Sisal Fibers; Rubber Composites; Mechanical Properties; Environment-Friendly; Vegetable Fibers \& Interfacial Adhesion

Received: Jun 16, 2017; Accepted: Jul 01, 2017; Published: Jul 06, 2017; Paper Id.: IJMPERDAUG20177

\section{INTRODUCTION}

The global trend towards a sustainable and environmentally friendly development prompted researchers to develop new materials from renewable sources, bio-degradable, atoxic, low cost like vegetable fibers. Natural fibers also have good thermal and sound insulations and have a lower abrasion rate, due to its low density. Moreover, as they decompose completely, there will be no waste generation at the end of the product life cycle. Rubber, an elastomer is an integral part of engineering and industrial products. At present, most of the products are developed using polymers and synthetic elastomers derived from petroleum products. The ongoing depletion of petroleum products and the toxic and non-biodegradable nature of synthetic materials prompted humans to think of finding and developing new composite materials based on naturally occurring materials. The present work is to develop, fabricate and characterize an elastomer composite using $100 \%$ natural materials like natural rubber latex and sisal leaf fibers. In this work, a $40 \%$ volume fraction untreated Sisal fibers are used to reinforce natural rubber latex (40\% Dry Rubber Content w/w). The specimen sheets are finally made by rolling in rubber rolling steel mills.

Morassi[1] suggested that sisal fiber can be considered as an alternative to glass fiber and can be used as a reinforcing plastic products in the automobile industry. Vegetable fibers like jute, sisal, ramie, pineapple etc. are used to reinforce polymer matrices[2,3]. Sisal fibers have a higher elastic modulus, high impact strength and good tensile and flexural strength compared to other vegetable fibers[4,5]. The inclusion of sisal fibers in epoxy resin matrix produces a composite material with hard and rigid properties[6]. Mercedes-Benz vehicles use vegetable fibers as reinforcement to make upholstery and polymer parts. The more and more use of vegetable fibers also help to generate additional rural and industrial jobs and incomes [7]. Researchers [8-10] have been involved a number of investigations 
on several types of natural fibers such as bamboo, kenaf, hemp, flax, and jute to study the effect of these fibers on the mechanical properties of composite materials. Reinforcing nature of natural fibers depends on the nature and amount of cellulose and its crystallinity [11]. The primary effect of fiber reinforcement on the mechanical properties of natural rubber composites includes increased modulus [12]. The hollow nature of natural fibers imparts acoustic and damping properties of the matrices [13]. Mechanical behavior of chemically modified Banana fiber reinforced polyester composites was studied by Pothan et al. [14]. Murali M.R.K. et al. studied natural fiber composite properties with Vakka, sisal, bamboo and Banana fibers as reinforcement [15]. Paul Wambua et al Studied the viability of Natural fibers as a replacement to Synthetic fibers [16]. Collier [17] studied the effect of cotton fibers in rubber. Effect of fiber diameter on mechanics of rubber composites was studied by Zhang et al.[18]. For soft rubbery composites, cellulose fiber has been found to give better reinforcement than glass or carbon fibers[19].

\section{Natural Rubber}

Latex is a white or yellowish opaque liquid with a specific gravity varying from 0.974 to 0.986 . It is a weak colloidal system of spherical or pear-shaped rubber globules in an aqueous serum. Composition of latex is Rubber 30-40\%; Resins 1-2.0\%; Proteins 2-2.5\%; Sugars 1-1.5\%; Ash 0.7-0.9\%; Water 55-65\%. The major commercial source of natural rubber latex is the Pará rubber tree (Hevea brasiliensis) indigenous to South America. Charles Marie de La Condamine introduced rubber to the Académie Royale des Sciences of France in 1736 [20]. In 1751, the first scientific paper on rubber presented by François Fresneau to the Académie that described rubber properties[21]. In India, commercial cultivation introduced by British planters. The first Hevea plantations were established at Thattekadu in Kerala in 1902. Today India is the world's 3rd largest producer and 4th largest consumer [22]. Rubber is basically a poly- Isoprene chains. Natural rubber is obtained from latex and is used to make many products including tyres, mattresses, gloves, swim caps, condoms, catheters, and balloons.

\section{Sisal Fiber}

Sisal fiber extracted from the leaves of the plant Agave Sisalana is one of the most widely used natural fiber cultivated commercially in large scale. It is considered as a viable alternative to the synthetic fibers. Sisal fiber is ecofriendly, chemical-free, non-toxic and odour-free. Its main components are cellulose, hemicelluloses, and lignin. India is a leading producer of sisal fibers. These fibers are used in making textile fibers, carry bags, mats etc. Sisal fiber properties:-

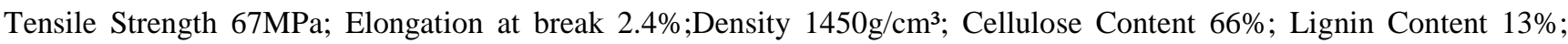
Hemi cellulose $13 \%$; Moisture content $10 \%$.

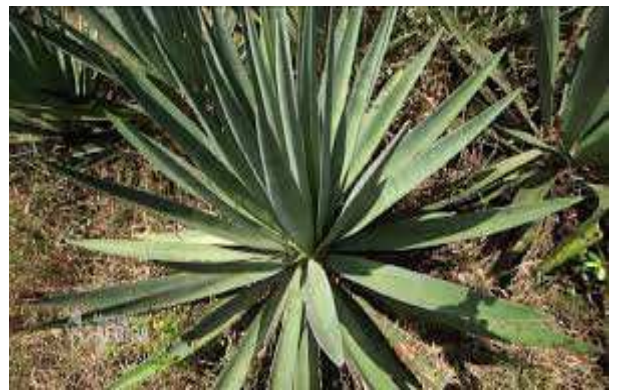

Figure 1: Sisal Plant

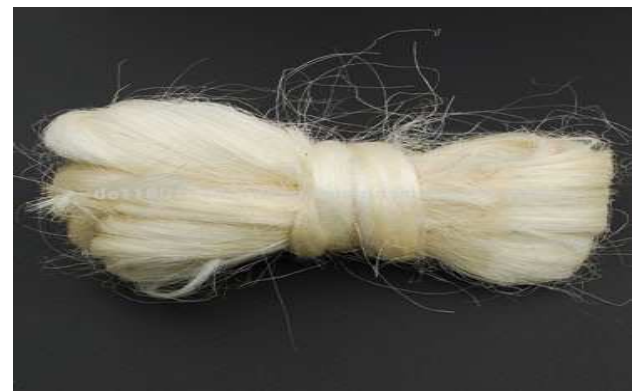

Figure 2: Sisal Fibers 


\section{MATERIALS AND METHODS}

\section{Materials}

40\% DRC Natural Rubber Latex, bSisal Fibers, Formic acid (for latex coagulation).

\section{Method}

Long sisal fibers are cut into the length (40mm) of the rubber latex molding trays. Fibers $40 \%$ volume fraction with respect to rubber are attached to an aluminium frame of $30 \mathrm{X} 40 \mathrm{~mm}^{2}$. Next, the $40 \%$ DRC rubber latex solution is poured into the aluminium molding tray of $30 \mathrm{X} 40 \mathrm{~mm}^{2}$ size and $1 \%$ formic acid mixed with it to facilitate latex coagulation. The Stretched sisal fiber net along with the aluminium frame is immersed into the latex in the tray. The arrangement is allowed to dry for $2 \mathrm{hrs}$ till it becomes a semi-solid. This semi-solid sheet is then taken out of the tray and rolled in steel rollers of a rubber rolling machine till the thickness reduced to $4 \mathrm{~mm}$. The rolled sheets are finally dried at sunlight for $72 \mathrm{hrs}$. Specimens for Tensile tests and Tear tests and hardness tests are cut from this sheet for both Longitudinal $\left(0^{\circ}\right)$ and Transverse $\left(90^{\circ}\right)$ unidirectional fiber orientations as per ASTM standards. The tensile and tear tests are done in a UTM as per ASTM D412 and ASTM D638 respectively. The hardness is found using a Shore A Durometer.

\section{RESULTS AND DISCUSSIONS}

Table 1: Results

\begin{tabular}{|c|c|c|c|c|c|c|c|}
\hline Sample & $\begin{array}{c}\text { Tensile } \\
\text { Strength } \\
\text { Max } \\
\left(\mathrm{N} / \mathbf{m m}^{2}\right)\end{array}$ & $\begin{array}{c}\text { Tear } \\
\text { Strength } \\
\text { Max } \\
(\mathrm{N} / \mathrm{mm}) \\
\end{array}$ & $\begin{array}{c}\text { Strain } \\
\text { Max. } \\
(\%)\end{array}$ & $\mathbf{E}=\sigma / \varepsilon$ & $\begin{array}{c}\text { Stress } \\
\text { at } 100 \% \\
\left(\mathrm{~N} / \mathbf{m m}^{2}\right)\end{array}$ & $\begin{array}{c}\text { Stress } \\
\text { At } 200 \% \\
\left(\mathbf{N} / \mathbf{m m}^{2}\right)\end{array}$ & $\begin{array}{c}\text { Stress } \\
\text { at } 300 \% \\
\left(\mathrm{~N} / \mathrm{mm}^{2}\right)\end{array}$ \\
\hline $\begin{array}{l}\text { Pure Rubber } \\
\text { Latex }\end{array}$ & 0.386 & 4.05 & 85.76 & $4.05 \times 10^{-3}$ & 0.373 & 0.0648 & $\mathbf{0}$ \\
\hline $\begin{array}{l}\text { SNR(Longitudinal } \\
\text { Fibers } 0^{\circ} \text { ) }\end{array}$ & 5.9 & 41.6 & 12.33 & $478.508 \times 10^{-3}$ & 0 & 0 & $\mathbf{0}$ \\
\hline $\begin{array}{l}\text { SNR (Transverse } \\
\text { Fibers } 90^{\circ} \text { ) }\end{array}$ & 0.678 & 8.38 & 349.59 & $1.9652 \times 10^{-3}$ & $\mathbf{0 . 3 2 3 7}$ & 0.368 & 0.4299 \\
\hline
\end{tabular}

\section{Tensile Strength}

(Figure 3) For Pure Natural rubber (NR) latex sample, the Tear Strength obtained is $0.386 \mathrm{~N} / \mathrm{mm}^{2}$. For the Composite latex reinforced with long, unidirectional Sisal fibers in the longitudinal direction $\left(0^{\circ}\right)$, the material showed a $1428.5 \%$ improved Tensile strength $\left(5.9 \mathrm{~N} / \mathrm{mm}^{2}\right)$ over pure rubber latex. The same sample BNR $0^{\circ}$ fibers exhibited a $758.8 \%$ more tensile strength than the sample Sisal- NR $90^{\circ}$ fibers.

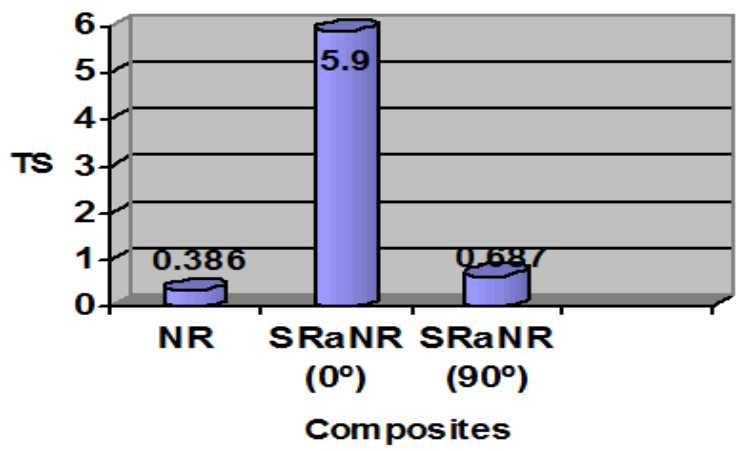

Figure 3: Tensile Strength (Mpa) 


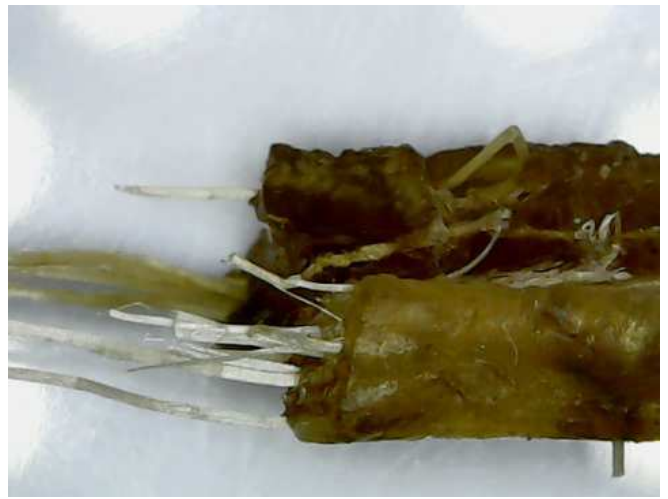

Figure 4: Microscopic Image- Tensile Failure Edge ( $0^{\circ}$ Fibers $)$

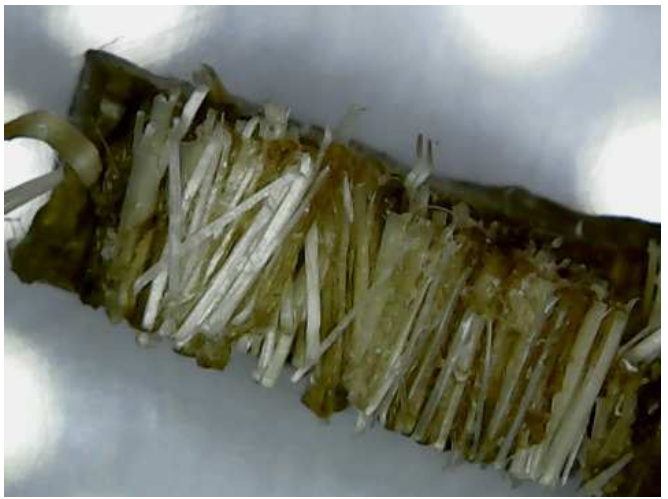

Figure 5: Microscopic ImageTensile Failure Edge $\left(90^{\circ}\right.$ Fibers $)$

Pure rubber latex has weak and fewer polymer chains than Vulcanized Rubber. It has a tensile strength of 0.386 $\mathrm{N} / \mathrm{mm}^{2}$. The latex sample Sisal-NR $0^{\circ}$ fibers have a good tensile strength over pure rubber latex, because of the effective matrix to fiber load transfer owing to the good fiber-matrix interfacial bonding developed. In addition, the dry sisal fibers having a coarse surface texture enabled the rubber to penetrate deep into it and make a good bonding leading to a virtually homogenous material.

In the case of transversely loaded fibers- rubber, the fibers are not subjected to tensile loading and only the fiberlatex interfacial adhesion offers a resistance to the longitudinal loading of the specimens. But this fiber-latex adhesion gives it a good load bearing capability than pure latex. But in longitudinal fibers-latex composites, the ultimate load is born by fibers. Hence the higher value for the tensile strength.

The microscopic images of the Tensile tested specimens failure edges for longitudinal (Figure 4) and Transverse (Figure 5) shows that fiber breakage occurred before the matrix failure indicating an effective matrix to fibers load transfer.

\section{Tear Strength}

(Figure 6) for Natural Rubber latex is obtained as $4.05 \mathrm{~N}-\mathrm{mm}$. For the sample Sisal fibers $\left(0^{\circ}\right)-$ latex, an increased Tear strength of $41.6 \mathrm{~N}-\mathrm{mm}$, an improvement of $927.1 \%$ over pure latex material.

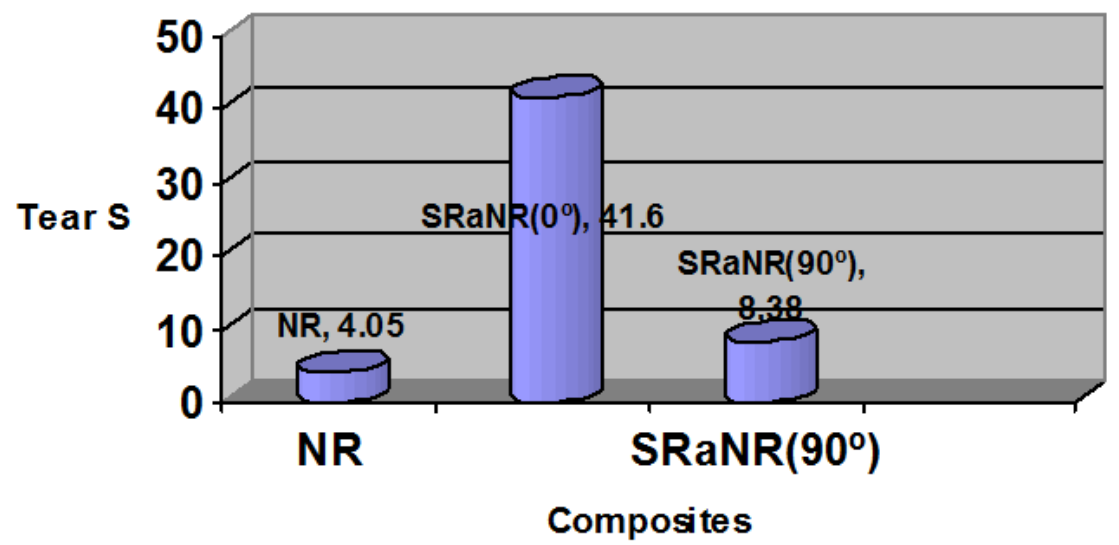

Figure 6: Tear Strength (N/mm) 


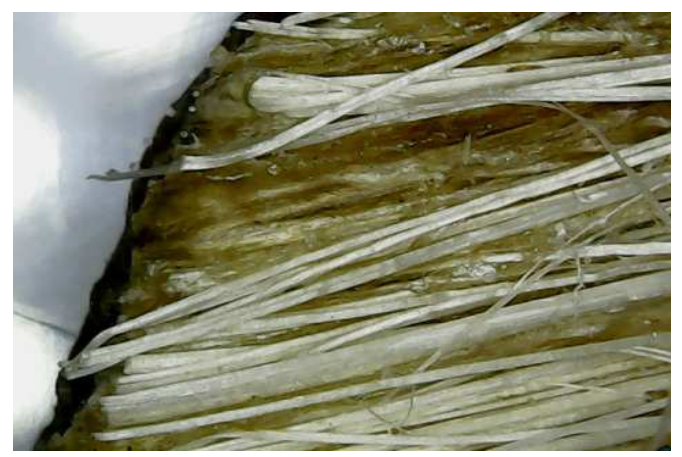

Figure 7: Microscopic ImageTear Failure Edge $\left(0^{\circ}\right.$ Fibers $)$

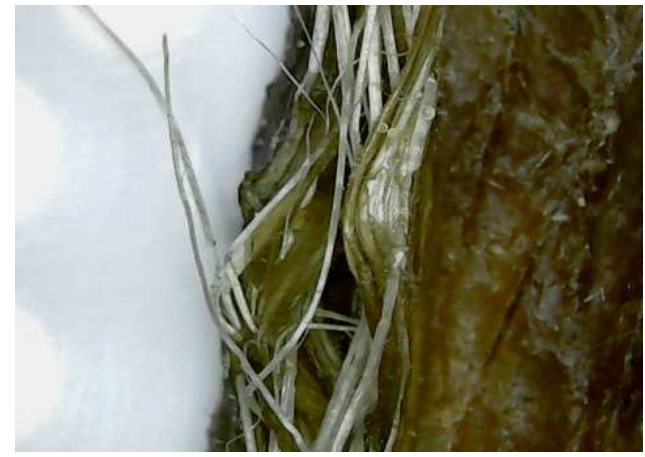

Figure 8: Microscopic ImageTear Failure Edge $\left(90^{\circ}\right.$ Fibers $)$

This improvement in Tear strength is due to the good Sisal fiber-latex adhesion achieved and the efficient matrix to fiber load transfer. The fiber breakage is observed before the matrix failure during the longitudinal loading. The latex composite sample with transversely loaded $\left(0^{\circ}\right)$ fibers showed a reduced $(8.38 \mathrm{~N} / \mathrm{mm})$ tear strength compared to longitudinally loaded Sisal fibers-rubber latex specimen. This is because the fibers are not subjected to axial loads in the second case. In the $90^{\circ}$ fiber oriented latex sample, the fibers act as filler and matrix bone only, and once the fiber-matrix bonding fails the matrix failure occurs. But this sample has better tear strength, $\%$ than pure rubber latex material.

It can be seen from the microscopic images of the torn edges of Tear tested specimens for longitudinal (Figure 7) and Transverse (Figure 8) fiber orientations, fiber breakage happened before the matrix failure indicating a good matrixfiber adhesion and an effective matrix to fibers load transfer.

\section{Stresses at $100 \%, 200 \%$ and $300 \%$ Elongations}

(Figure 9) At $100 \%$ elongation the maximum stress $\left(0.373 \mathrm{~N} / \mathrm{mm}^{2}\right)$ is for pure latex, followed by SRaNR (Transverse loaded fiber-latex $0.3237 \mathrm{~N} / \mathrm{mm}^{2}$ ). For the sample SRaNR (Longitudinally loaded fibers), fiber breakage occurred before the $100 \%$ elongation itself. For $200 \%$ material elongations best stress value is for $90^{\circ}$ fibers Sisal-NR $\left(0.368 \mathrm{~N} / \mathrm{mm}^{2}\right)$ followed by pure latex $\left(0.0648 \mathrm{~N} / \mathrm{mm}^{2}\right)$.

\section{Stesses at $100,200 \& 300 \%$}

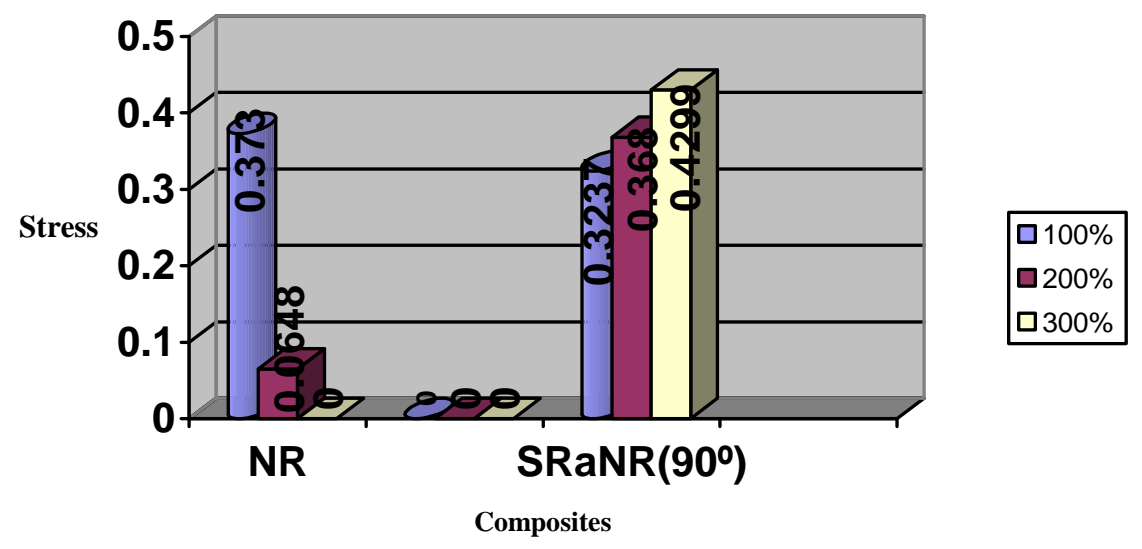

Figure 9: Stresses at $100 \%, 200 \% \& 300 \%$ 


\section{Comparison of Modulus of Elasticity (E): (Figure 10)}

The maximum values of Young's Modulus or Modulus of Elasticity (E) are obtained for $0^{\circ}$ fibers Sisal- latex composite $\left(478.508 \times 10^{-3}\right)$. This is followed by pure latex which has an E of $4.501 \times 10^{-3}$ and lastly by $90^{\circ}$ fibers SisalNR which has a value of $1.9652 \times 10^{-3}$. Higher the values for $\mathrm{E}$, the material is less elastic and more rigid. And the lower value for $\mathrm{E}$ indicates higher elasticity and lower rigidity of the material.

\section{Elastic Modulus E (X10-3)}

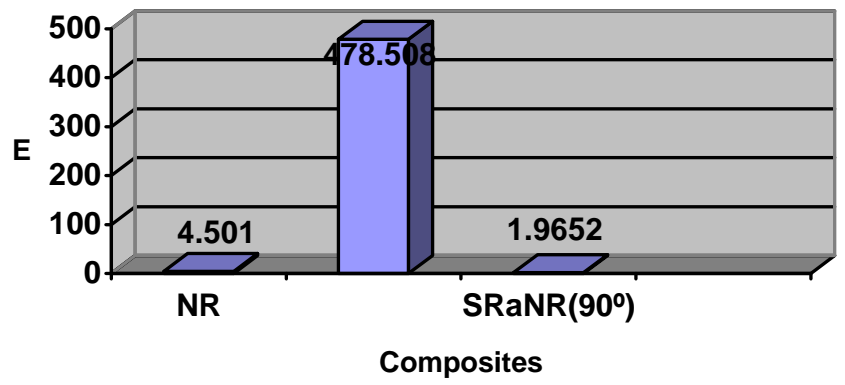

Figure 10: Modulus of Elasticity (E)

The transverse $\left(90^{\circ}\right)$ loaded fibers-latex composite shows a lower modulus than pure latex, because, in $90^{\circ}$ fiber SNR once the fiber-latex matrix bonding becomes weak or fails, the material becomes heterogeneous and shows more plastic nature compared to pure latex which retains its carbon chains till its failure.

\section{Hardness}

(Figure 11).There is not much difference for the Hardness of the developed composites. Pure latex has a hardness of 30 Shore A, while the other two samples loaded with $40 \%$ raw Sisal fibers loaded in the longitudinal $\left(0^{\circ}\right)$ and transverse $\left(90^{\circ}\right)$ directions exhibited a hardness of 40 Shore A. This is due to the greater hardness of the filler material- Sisal fibers in the latex composite.

The fiber orientations do not influence the hardness of the composite material. Only the fiber volume content and fiber hardness influence the composite hardness.

\section{Hardness (Shore A)}

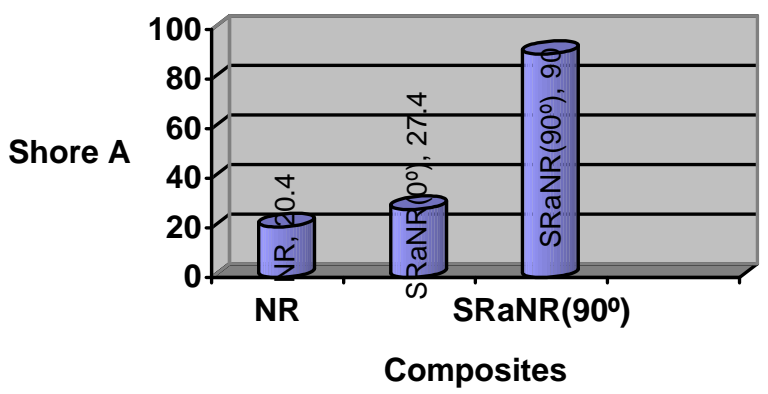

Figure 11: Hardness 


\section{CONCLUSIONS}

The Continuous Sisal fibers- Natural Rubber Latex Composite material developed, showed improved mechanical properties like tensile strength, tear strength and hardness. The longitudinal $\left(0^{\circ}\right)$ loaded Sisal fiber-latex specimen gave an increase of $1428.5 \%$ in tensile strength over pure rubber latex and an increase of $927.1 \%$ in tear strength over pure latex for $40 \% \mathrm{v} / \mathrm{v}$ fiber loading. The hardness of the developed materials also improved compared to pure latex. These materials can find a lot Engineering, Industrial and commercial applications and product developments.

\section{FUTURE SCOPE}

In this work, $40 \%$ fiber volume was chosen as optimum value based on a literature survey. Materials with different fiber volume contents may be developed for specific applications. This reduces the latex usage and utilization of more Sisal waste fibers having unique specific strengths.

\section{ACKNOWLEDGEMENT}

Authors acknowledge the support given by the Department of Mechanical Engineering, Noorul Islam University, T.N., India for completing this work.

\section{REFERENCES}

1. Morassi J O, Fibras Naturais; aspectos gerais e app aplicacao na industria automobilistica, Mercedez Benz of Brazil; 1994.

2. Mc. Laughlin EC, The strength of bagasse fiber reinforced composites, Journal of Material Science, 1980, 15(4), 886-890.

3. Prasad S V, Pavithran C, Rohatgi PK, Alkali treatment of coir fibers for coir-polyester composites, Journal of Materials Science Letters, 1983, 18(3); 1443-1454.

4. Pavithran C, Mukherjee P S, Brahmakumar M, Damodaran A D, Impact Properties of natural fiber composites. Journal of Materials Science Letters, 1987, 6(8), 882-884.

5. Pavithran C, Mukherjee P S, Brahmakumar M, Dmoran A D, Impact performance of Sisal-Polyester Composites, Journal of Materials Science Letters, 1998; 7(8); 825-826.

6. Oksman K, Wallstrom L, Berglund L A, Toledo Filho R P, Morphology and Mechanical Properties of Unidirectional SisalEpoxy Composites, Journal of Applied Polymer Science 2002; 84(13); 2358-2365.

7. Mattoso L H C, Ferreria F C, Carvalho AAS, Sisal fiber; Morphology and Applications in Polymer Composites, Proceedings of the International Symposium on Lignocellulosic-Plastics Composites; 1998; Sao Paulo-SP.

8. Chandramohan D. and Marimuthu. K (2011) "Tensile and Hardness Tests on Natural Fiber Reinforced Polymer Composite Material" IJAEST, Vol. 6, pp.97-104

9. Herrera-Franco, P.J., Valadez-Gonzalez, A. (2005) "A study of the mechanical properties of short natural-fiber reinforced composites", Composites Part B: Engineering, Vol. 36/8, pp 597-608

10. Ishak M. A., Maleque F., Belal Y. and Sapuan S.M. (2007) "Mechanical Properties Study of Pseudo-Stem Sisal Fiber Reinforced Epoxy Composite”, The Arabian Journal for Science and Engineering, Vol. 32, pp.359-364.

11. A.A.Collier, Rubber toughened engineering plastics, 1994 Chapman \& Hall.

12. Nilza.G.Justiz-Smith, G.Junior Virgo, Verman.E.Buchanan Potential of Jamaican Sisal, Coconut coir and bagasse fibers as reinforcement in Composites Materials, Journal of Materials Charecterisation (2005). 
13. A Study on the Mechanical Properties Short Natural Fiber reinforced composites Part B 36 (2005) 597-608.

14. Laly A., Pothan, and Sabu Thomas (2003) "Polarity parameters and dynamic mechanical behavior of chemically modified Sisal fiber reinforced polyester composites", Composites Science and Technology, Vol. 63, pp. 1231-1240.

15. Murali Mohan Rao K., Mohana Rao K. and Ratna Prasad A.V. (2010) "Fabrication and testing of natural fiber composites: Vakka, sisal, bamboo and Sisal”, Materials and Design, Vol.31/1, pp. 508-513.

16. Paul Wambua, Jan Ivens, and Ignaas Verpoest (2003) "Natural fibers: can they replace glass in fiber reinforced plastics?" Composites Science and Technology, Vol.63, pp.1259-1264.

17. Collier AT., U.S.1000781, August 15, 1911.

18. Zhang Zhicheng, Zheng Yuansuo., Xiandai Huagong 2002,22,38.

19. Murthy V.M., De S.K., polymer.Eng.Revs.1984, 4, 313.

20. “Charles Marie de la Condamine”. bouncing-balls.com.

21. John Tully. 2011. The Devil's Milk: A Social History of Rubber. NYU Press

22. "Natural rubber in India". 